\title{
Study on the Strategy of Young Retirees' Human Resource Development
}

\author{
Li Dan \\ School of Economics and Management \\ Beijing Jiaotong University \\ Beijing,China \\ lidan083@126.com
}

\begin{abstract}
Under current retirement policy, a large number of Yong Retirees' HRD do not continue to be developed and human resources are idle or waste. In the view of this, firstly,this article analyzes the retirement policy and the present situation of young retiree human resources development and the conclusion is that part of the quantity and the proportion of this resource is growing rapidly, but the structure is not balanced. Secondly, this paper analyzed the utilization effect from the angle of economic effect and social effect, and then concludes that on one hand the development of the old human resources it can meet the needs of social and economic development. On the other hand, to be able to meet the needs of the elderly themselves. At last, the human resources development strategy is put forward.
\end{abstract}

Keywords-Young Retirees; Human Resource Development; Strategy

Along with the development of our economic and medical technical level,the population average life expectancy have extended and the aging of the population degree deepened. According to various data statistics, our country has stepped into aging society and the economic development and social security are under tremendous pressure. In the case of current retirement policy in our country, a lot of young retiree's human resources are idled and wasted. Based on the current situation,this paper explores the development of the young retired human resources under the current retirement policy, and argues that the research in the young retired human resources development is significance.

\section{RESEARCH CATEGORY DEFINITION}

This paper study on the young retirees, which conform to retirement and terminate the labor obligations with the employer in accordance with the national law and regulations. The men in the age between 60-69 and women between 50-69 are young retirees.

Define this part of the group needs to satisfy two conditions: the professional ability and willingness. Professional ability refers to the industry knowledge, career development and entry-level skills and professional willingness refers to the mind continue to work.In this paper, according to the particularity of the object, young retirees' human resource development is defined as: the development of the people whose age is before 69 and own the professional ability and willingness.

\section{STATUS QUO OF YOUNG RETIREES}

\section{A. Young retired human resources characteristics}

\section{1) An increasing trend of human resources}

With the development of our country's economy and the progress of the society, people's living standard raise continuously, and the life span of population average from 1990, 2000 to 2010 extend continuously.

TABLE I. LIFE EXPECTANCY IN CHINA

\begin{tabular}{|c|c|c|}
\hline Age & Number & Proportion \\
\hline $0-14$ & 222459737 & $16.60 \%$ \\
\hline $15-59$ & 939616410 & $70.14 \%$ \\
\hline$\geq 60$ & 177648705 & $13.26 \%$ \\
\hline$\geq 65$ & 118831709 & $8.87 \%$ \\
\hline
\end{tabular}

In the case of a longer life expectancy, China's aging population gradually increased. The number of population over the age of 60 accounts for more than $10 \%$, over the age of 65 more than $7 \%$, under the of e age of 14 less than $30 \%$. Our country has entered the aging society with a national definition and table 2 represents the sixth census in China based on the distribution of age.

TABLE II. POPULATION DISTRIBUTION

\begin{tabular}{|c|c|c|c|}
\hline Year & The national average & Man & Women \\
\hline 1990 & 68.55 & 66.84 & 70.47 \\
\hline 2000 & 71.4 & 69.63 & 73.33 \\
\hline 2010 & 73.5 \\
\hline
\end{tabular}

Source: sixth national population census data

Compared with the fifth national census in 2000, a $6.29 \%$ drop in the proportion of population aged 0 to 14 , a $3.36 \%$ rise in the proportion of population aged 15 to 59 , a $2.93 \%$ rise in the proportion of population aged above 60 and a $1.91 \%$ rise in the proportion of population aged above 65 . The population over the age of 60 and 65 in China has increased visibly.

2) Quality of human resources has a comparative advantage

With the improvement of living standards, the life expectancy in our country has reached 73 years old in 2009, and most of the young old people has good physical and mental conditions. The senior researchers and senior professors have a wealth of experience and skills. Although physical strength of many old people declined, their logical thinking ability, understanding ability and creation ability are strong. Many of them choose to return to their work in order to meet the demand of economy or realize their own value. This is the society increasingly high-profile "silver talent pool".

\section{B. Young retirees' human resources development situation}

\section{1) Number and proportion increase gradually}

Compared the fifth and sixth census data, employment population aged 60 and above growth rate reached $55 \%$ in the 10 years. And the growth rate of population aged 65 years and above up to $81.9 \%$. Thble 3 shows the number and proportion 
of the elderly employment.

TABLE III. THE NUMBER AND PROPORTION OF THE ELDERLY EMPLOYMENT

\begin{tabular}{|c|r|c|c|c|c|c|c|}
\hline \multirow{2}{*}{ Year } & \multirow{2}{*}{ Age } & \multirow{2}{*}{ No. elder } & \multirow{2}{*}{$\begin{array}{c}\text { No. elderly } \\
\text { employment }\end{array}$} & \multicolumn{2}{|c|}{ Man } & \multicolumn{2}{c|}{ Woman } \\
\hline \multirow{3}{*}{2010} & & & & & & \\
\cline { 5 - 8 } & & $1.3 \mathrm{E}+08$ & 42908141 & 27094673 & 63.15 & 15813468 & 36.85 \\
\cline { 2 - 8 } & $60-64$ & 41703848 & 20837660 & 13040503 & 62.58 & 7797157 & 37.42 \\
\cline { 2 - 8 } & $\geq 65$ & 88274022 & 22070481 & 14054170 & 63.68 & 8016311 & 36.32 \\
\hline \multirow{3}{*}{2000} & $\geq 60$ & 96969646 & 27684461 & 20426048 & 73.78 & 7258413 & 26.22 \\
\cline { 2 - 8 } & $60-64$ & 33976254 & 15548411 & 11047185 & 71.05 & 4501226 & 28.95 \\
\cline { 2 - 8 } & $\geq 65$ & 62993392 & 12136050 & 9378863 & 77.28 & 2757187 & 22.72 \\
\hline
\end{tabular}

Source: census data, China statistical yearbook data

This paper analysis the retired human resources development based on each family. The proportion of retired human resources to return to work from every family also rise.Table 4 is a employment situation of the four main urban residents in 2008,2009 and 2010.

In table 4,the "p" represent proportion, " $\mathrm{B}$ " is Beijing," " $T$ " is Tianjin, " $S$ " is Shanghai and " $C$ " is Chongqing.

TABLE IV. HOUSEHOLD POPULATION EMPLOYMENT STATISTICS(AVERAGE EVERY FAMILY)

\begin{tabular}{|c|c|c|c|c|c|c|c|c|c|}
\hline & \multicolumn{3}{|c|}{2008} & \multicolumn{3}{c|}{2009} & \multicolumn{3}{c|}{2010} \\
\hline & $\begin{array}{c}\text { No. } \\
\text { retirees }\end{array}$ & $\begin{array}{c}\text { No. } \\
\text { rework }\end{array}$ & $\begin{array}{c}\mathrm{P}(\%) \\
\text { retirees }\end{array}$ & $\begin{array}{c}\text { No. } \\
\text { rework }\end{array}$ & $\begin{array}{c}\text { P(\%) } \\
\text { retirees }\end{array}$ & $\begin{array}{c}\text { No. } \\
\text { rework }\end{array}$ & $\mathrm{P}(\%)$ \\
\hline $\mathrm{B}$ & 0.72 & 0.12 & 16.67 & 0.64 & 0.11 & 17.18 & 0.61 & 0.11 & 18.03 \\
\hline $\mathrm{T}$ & 0.75 & 0.13 & 17.33 & 0.76 & 0.13 & 17.10 & 0.76 & 0.13 & 17.10 \\
\hline $\mathrm{S}$ & 0.63 & 0.13 & 20.50 & 0.66 & 0.15 & 22.73 & 0.65 & 0.15 & 23.07 \\
\hline $\mathrm{C}$ & 0.66 & 0.09 & 13.63 & 0.68 & 0.13 & 19.12 & 0.6 & 0.16 & 26.67 \\
\hline
\end{tabular}

2009, 2010 Chinese household population employment statistics

This table shows that the proportion of retired employment in this four developed city is increasing year by year and Shanghai is obviously higher of all.

\section{2) Industry structure is unbalanced}

According to census data analysis, the vast majority of the elderly population are engaged in the first industry and agriculture is still the main industry of the old employment in our country. There can be concluded that there are many vacant jobs for the retirees and the society needs the elderly to participate in social work.

TABLE V. THE INDUSTRY STRUCTURE OF POPULATION AGED 60 AND ABOVE

\begin{tabular}{|c|c|c|c|}
\hline Industry & \multicolumn{3}{|c|}{ Proportion(\%) } \\
\hline Total & Subtotal & Man & Women \\
\hline ecological-economic & 91.01 & 88.67 & 95.02 \\
\hline Extractive industries & 0.17 & 0.25 & 0.04 \\
\hline manufacturing & 2.36 & 2.99 & 1.29 \\
\hline Supply industry & 0.08 & 0.12 & 0.01 \\
\hline Construction industry & 0.47 & 0.71 & 0.05 \\
\hline Geology industry & 0.04 & 0.06 & 0.01 \\
\hline Transportation industry & 0.28 & 0.41 & 0.06 \\
\hline Wholesale and retail & 2.58 & 2.87 & 2.07 \\
\hline Financial insurance & 0.07 & 0.1 & 0.02 \\
\hline Real estate industry & 0.05 & 0.07 & 0.02 \\
\hline Social services industry & 0.81 & 0.99 & 0.49 \\
\hline Health and sports & 0.5 & 0.65 & 0.26 \\
\hline Education culture & 0.63 & 0.86 & 0.25 \\
\hline Scientific research & 0.1 & 0.13 & 0.03 \\
\hline The state organs & 0.77 & 1.01 & 0.35 \\
\hline Others & 0.08 & 0.1 & 0.04 \\
\hline
\end{tabular}

Source: national bureau of statistics, the census data, China's employment situation in the elderly

\section{THE UTILIZATION EFFECT ANALYSIS OF YOUNG RETIREE HUMAN RESOURCES}

Younger retirees as a part of the society play a role that can not be ignored and the development of the young retirees' human resources caused great repercussions in society.

\section{A. Economic effect analysis}

1) The effect to human capital by use young retirees' human resources

In our country the longer years of education, the higher degree one can reach and Dr. graduate with an average age of 33.17 years old, the average time required to study for a doctoral degree is 3.54 years. The average age for a Dr. to get subtropical high title is 34.11 years old. According to Dr. Quality report of the People's Republic of China, the percentage of women in our doctoral students has increased from $21.9 \%$ in 1998 to $35.7 \%$ in 2006 , but they follow the same age at retirement. Even though they retired at age 60, average working years for 27 years or less after graduation, which makes the ones with a longer education has a shorter working time. In this case, the newly retired young people want to continue to work strongly.

\section{2) The effect to labor market by use young retirees' human} resources

On the one hand, the condition of great employment pressure, an aging of the population, incomplete human resource structure, general talent surplus and senior talent shortage cause huge difficulties in the development of human resources in our country. At the same time,even though our country population base is big, every year there are a lot of new labor need to work.

In current human resources structure, on the other hand, human resources tomography has become a problem which cannot be ignored. To mobilize young retired human resources talents can help alleviate the status quo of human resource structure is not reasonable. Some of the retired people were trained in system of education and the majority of people experienced and has reached a very high level in their works. Developing young retired human resources can compensate for the gap of loss top talent. The elder can also pass their valuable experience and life experience to young people to help young people grow up fast.

\section{B. Social effect analysis}

1) The interaction to social consciousness by use young retirees' human resources

First, under the influence of the traditional Chinese etiquette custom, "respect for the elderly" is seen as a virtue. Under the influence of this idea, the enterprise is not willing to use the old because they believe that will increase cost and family don't want old people to work because they afraid of being seen as "not filial". But the idea of remaining years can not adapt to social development already. Not only can it contribute to the development of the society and economic progress though elderly human resource back to work on, but also these elderly people who go back to work can realize their own value.

Second, the elderly in the physiological aspect is considered by most people as "vulnerable groups" and the burden of enterprises. So the enterprises hire highly educated, 
younger employees as the main force of enterprises. "Ageism" seems to have spread in the society and this makes the elderly get more social exclusion rather than to get more care. At the same time, old ideas and did not pay attention to the knowledge update is also a limiting factor for the development of the human resources.

\section{2) The interaction to endowment patterns by use young} retirees' human resources

First of all, the old-age security system in China starts late and is not perfect. As the aging of the population increasing, the elderly pension problem has become a serious problem. China's population over the age of 60 has reached the category of an aging society, and China's aging population will continue to grow in the future. The development of elderly human resource can alleviate the pressure of the society.

Second, long-term stay-at-home after retirement to the people who want to go back to work will increase the burden of thinking. The small life circle and monotonous life content are not conducive to body and mind health. Developing old human resources can expand the life circle for those who have the willingness to go back to work, and promote emotional communication, improve their physical and mental health.

\section{THE STRATEGY OF YOUNG RETIREES' HUMAN RESOURCE DEVELOPMENT}

Based on the above analysis, this paper built a preliminary development strategy.

\section{A. Engaged in the old industry}

Engaged in the old industry is one can work after retirement rely on the knowledge, skills and work experience accumulated before retirement.

\section{1) Share information}

Young retirees has accumulated rich experience in decades of work.The development of this part is easy and more likely to be accepted by the society. The most important thing to engaged in the old industry is share information. On the one hand, enterprise's recruitment information should convey to job seekers timely; on the other hand, candidate's age, length of service, professional titles and specialty information should be known transparently.

2) Reform of the retirement system and implement flexible retirement system step by step

Under the current retirement system, China's retirement age is 56.1 years on average. Table 6 is the average retirement age in different ages.

TABLE VI. THE AVERAGE RETIREMENT AGE IN DIFFERENT AGES

\begin{tabular}{|l|l|l|l|l|l|l|l|}
\hline Ages & Total & $60-64$ & $65-69$ & $70-74$ & $75-79$ & $80-84$ & $85+$ \\
\hline Total & 56.1 & 55.0 & 55.4 & 56.7 & 58.0 & 59.9 & 62.7 \\
\hline Man & 59.3 & 57.6 & 58.0 & 58.5 & 59.6 & 61.4 & 63.4 \\
\hline Woman & 52.4 & 51.1 & 51.5 & 53.4 & 55.1 & 57.6 & 60.9 \\
\hline
\end{tabular}

Source: the status of urban and rural elderly one-time survey data

Under the situation of life expectancy extension in China, the number of elderly people to accept social support is beyond our capacity of social pension for pension already has a big gap. "Intergenerational support" has become a society problem now.
Flexible retirement system is refers to one can choose their retirement time according to their age and health in the allow age range regulated by government. From October 1, 2010, Shanghai has to implement flexible retirement system in our country. Those who has a professional technical position qualifications, professional engineer certificate and the staff need by enterprise can practice the flexible retirement system.

Flexible retirement system can be implemented in stages, steps and regions.First it can changes the women' retirement age moderately.Second it can be piloted in the more developed cities and regions. And then it can be implemented depending on the talent. We can make this part of the senior skilled worker to delay a couple of years avoiding the loss of talent. When to implement flexible retirement system, of course, the most important is the voluntary of workers.

\section{B. Engaged in the new industry}

Engaged in the new industry is one participate new work after retirement different from the old one completely. There are a lot of people try a new job they like much but have no time when they are in job.

\section{1) Strengthen the elderly training,developing the elderly} education

Elderly human resource development is a systems engineering and it involves every field of the society. Developing the education and training system for the elderly people who had ever engaged in related work is particularly important.

"Never too old to learn" has been accepted by most people and lifelong learning and lifelong education also should be taken seriously. The development of old age education and university foe elderly can let the elder consume less energy to harvest more knowledge through professional and systematic knowledge of learning.

2) The government give preferential policies to support the young retirees' human resource development

The enterprise is maximize their own interests for the purpose in today's market competition mechanism.Most companies will not hire retired old people until there is preferential policy to support its development. The government can introduce competition mechanism and let the elderly to participate in the fair competition. At the same time, enterprises can arrange appropriate positions and give appropriate benefits and rewards to the elder.By this way, both sides will get mutual benefit and common gain.

\section{REFERENCE}

[1] Honglan Li.Analysis of the feasibility of extending the retirement age[M].Social Security Publishing House,2011.pp.12-14,

[2] Dasong Deng.The sensitivity empirical research of pension funds[M].The social security system, 2010,pp.18-20,

[3] Qingrui Liu,Hongjun Miao.The policy research for postponing retirement age under population Aging[M].2010.pp.4-6,

[4] Xugu.The retirees 'human resource development in city[M].June,2011.pp.6-7.

[5] Gang Jin.The Analysis on the Status and Problems of China' s Retiring Age and the Necessity of Extending Retiring Age[J].Social Security Studies,2010.pp.11-13.

[6] Baohua Li,Choice Mechanism of Retirement Age:from the Perspective of Human Capital and Social Security[J].Journal of Xinjiang Finance \& Economy Institute.pp.25-26. 
[7] Qingbo Gao,Discussions About Statutory Pensionable Age in China[J].Social Science of Beijing, July2007.pp.11-12.

[8] Yufeng Xu,The Consideration to Extend the Retirement Age at Present Economic Situation[J].Economic Research Guide,2010.pp.116-117.

[9] Bin Xiong.The Population Aging and the Development of Human Resources of the Old in China[D].Journal of Chongqing Institute of Technology.2002.
[10] Fei Zhao,Population Aging in China and the Elderly Human Resource Development[D].Jilin university,June 2011. 